\title{
The Impact of Liberalism on the Idea of Militarism according to the Doctrine of Zeev Jabotinsky
}

\author{
David Schwartz ${ }^{\text {, Daniel Galily }}{ }^{2}$ \\ ${ }^{1}$ Department of Political Science, Bar-Ilan University, Ramat Gan, Israel \\ ${ }^{2}$ Los Angeles University, Los Angeles, CA, USA \\ Email: daniel.galily@gmail.com
}

How to cite this paper: Schwartz, D., \& Galily, D. (2017). The Impact of Liberalism on the Idea of Militarism according to the Doctrine of Zeev Jabotinsky. Open Journal of Political Science, 7, 283-290. https://doi.org/10.4236/ojps.2017.72023

Received: January 13, 2017

Accepted: April 23, 2017

Published: April 26, 2017

Copyright (c) 2017 by authors and Scientific Research Publishing Inc. This work is licensed under the Creative Commons Attribution International License (CC BY 4.0).

http://creativecommons.org/licenses/by/4.0/

\section{(c) (†) Open Access}

\begin{abstract}
From the late 1970s, there was a debate on Jabotinsky's approach to the idea of militarism. The argument revolved around two different opinions on the topic. The first opinion among the researchers saw his idea of militarism as an active concept that expresses correspondence between his opinions and the fascist ideas in Europe. It is certainly possible to see that the findings are commensurate with the opinions of the researchers who argue that according to Jabotinsky, the liberal outlook pertains to the person's natural rights as a person, in contrast to classic and pure liberalism, which acts in the name of the free society. According to examination of his writings, it is safe to assume that, for Jabotinsky, the liberal values were more dominated than the militaristic values.
\end{abstract}

\section{Keywords}

Jabotinsky, Liberalism, Militarism

\section{Introduction}

The topic of the research is the attitude of one of the Zionist thinkers at the beginning of the $20^{\text {th }}$ century, Jabotinsky, towards the idea of militarism. Jabotinsky was the ideological leader of the secular right in the Land of Israel and in the Jewish communities in the world, and his thought still has dominant importance regarding different actions of the political organizations that belong to the Israeli right today.

According to his writing, Jabotinsky did not agree with the actions of the Zionist socialist movement. He did agree with the socialist movement, which at that time was the head of the Zionist movement, that it is important to imple- 
ment the Zionist ideology by building a Jewish institution, economy, and a fighting force. But, on the other hand, he didn't agree to the fact that the socialist movements are operating according to the writings of the ideological thinker Karl Marx in the building of the Jewish State.

Namely, they are strengthening the working class for a future class warfare against the bourgeoisie, after which the expectation is to build a dictatorship of the proletariat in the Jewish state, which will create absolute equality between the classes in the population.

From the intention to create an ideological opposition to the Zionist-socialist movements, Jabotinsky decided to write a complete ideology from the foundation about the Jewish State that will be established. The thinking included explanations that were detailed on the rational and scientific level on every possible aspect in the Jewish State that included areas such as governing methods, welfare institutions, legal institutions, and economic policy (Jabotinsky, 1934a).

Jabotinsky always believed in the existence of a Jewish military organization. In 1915 he worked with Joseph Trumpeldor to establish a Jewish brigade in the British military to fight as an independent Jewish power. In the year 1920, following his opposition to the policy of restraint that the Hagana implemented following the riots in the country, Jabotinsky decided to establish groups of Jews to fight the Arabs. This course of action led to his selection to stand at the head of the underground military wing of the Zionist-Revisionist movement, known as the Etzel (also known in English as "The Irgun”).

Jabotinsky always believed in the importance of militarism in the Jewish community. The objective of this research is to examine in a precise manner on how Jabotinsky referred to the idea of militarism. The work examines Jabotinsky's opinions on the idea of militarism as ideology, the impact on the State and society, and its influence on the Hebrew community and the Jewish people (Naor, 2004a). However, because he was known as a supporter of Italian Liberalism, the question arises: how does his liberal ideology influence his ideals on militarism? Let us look what the Research Literature has to say on that issue.

\section{Research Literature}

1) Militarism

Militarism is an ideology that emphasizes the importance of military force, even regardless of Militarism security needs, and sees the military element, which purpose and obvious target civil society rely. While preparations militaristic can be interpreted as a practical necessity connected with the protection of the state, militarism is a broader concept, a doctrine that suggests that there strive military.

Militarism estimated the extent to which war and preparations for war seen as acts of social normality, even unwanted. Militarization of society legitimizes the heavy burden that the preparations for war (especially the actual execution) impose on society (Cohen, 1996; Bacevich, 2005).

Militarization is a process of values emphasizing them military, military policy 
and military preparedness of frequent transfer of civil functions to the military authority. Militarization guess when a society dies is in crisis, or when it is threatened, the best way to overcome the crisis or the threat is to strengthen the army. Two important indicators are the militarization of public spending for security purposes, and particularly the percentage of expenditures directed at military purposes, and discussion on the measures taken to military or actual solution to problems and conflicts are essentially political or economic (Vagts, 1959).

2) Liberalism

Liberalism is an individualistic political philosophy that based on the principle of human liberty. Liberalism supports constitutional governance principles such as freedom of religion, property rights, freedom of expression and equality before the law and opposes the policy of an authoritarian regime (Adams, 1998).

It is common to view liberalism as a political movement of Enlightenment thinkers, then formulated into a coherent conception among philosophers and economists in the West. English philosopher John Locke, in the 17th-century, promoted the idea of natural rights that say that all persons have the right to life, liberty and property. The source of these rights, according to Locke, is not by government decree or by the kindness of the people in power, but rather by the nature of man (Locke, 1689).

\section{Jabotinsky's Liberalism}

The roots of this approach are found in the book of Moshe Bela, The World of Jabotinsky (1972). In this book Bela maintained that Jabotinsky believed that a true democracy cannot exist without liberal principles. Therefore, he believed in the democratic election of representatives of the Jewish people in the future Jewish State, but in addition he believed that the main meaning of modern democracy is to see to the rights of the minorities (Bela, 1972).

The historian Shechtman maintained in his book Ze' ev Jabotinsky-Story of His Life (1987) that Jabotinsky was the harsh critic of the Orthodox Jewish population in Europe in that he believed that the spirit is not built by religious coercion but by the universal principles of justice and morality (Shechtman, 1987).

Last, in 2004 the researcher Naor from the Jabotinsky Institute wrote a comprehensive article titled "The Constitutional Outline of Ze'ev Jabotinsky for the Jewish State in the Land of Israel”, which described all the liberal principles in Jabotinsky's thinking, including full equality for women, human rights, minority rights, freedom of expression, and freedom of occupation. Researches on Jabotinsky's liberal thinking conducted later were based on these aforementioned researches (Naor, 2004a).

The research question is as follows. Is the liberal thinking of Jabotinsky expressed in his ideas on militarism? The relationship between the idea of militarism and the theory of liberalism has never been examined.

The research hypothesis is that in the writings of Jabotinsky his liberal opinions influenced his opinions on the idea of militarism. Namely, in contrast to the thesis of Avineri, the research hypothesis is that the idea of militarism, ac- 
cording to Jabotinsky, was not commensurate with the fascist idea but more with the liberal idea (Avineri, 1980).

According to his writings, it is possible to assume that Jabotinsky objected to the Marxist thinking that guided the actions of the socialist movement that controlled the institutions in the Jewish settlement. Therefore, when Jabotinsky searched for a fundamental assumption that would constitute a response to socialism, when he put his materialism on paper, he saw Western liberalism as a counter-solution to the economic policy of Mapai.

In his writing, Jabotinsky saw liberalism to be a positive solution and believed that it constitutes a fundamental idea that needs to be anchored in the Jewish State. This attitude placed him in the opposition against the socialist movement that in those days controlled the World Zionist Congress, the General Assembly, and the institutions of the Jewish communities in the land of Israel. He saw the maximal realization and defense of the individual's rights to be the guideline of the ideology of his movement (the Revisionist Movement), towards the construction of the Jewish State and as the central basic assumption of his thinking:

"Had my Creator blessed me with wisdom and knowledge sufficient for the formulation of a philosophical method, I would establish and build my entire method: In the beginning God created the individual; every individual is a king equal to his peer and the evil is a 'king' as well; it is better for the individual to sin against the public than for society to sin against the individual; society was created for the good of the individuals, and not the other way around; and the end in the future, the vision of the days of the Messiah - is the Garden of Eden of the individual ..." (Jabotinsky, 1936)

Jabotinsky strongly objected to the statements of the socialist movement that called his movement fascist. He asserted that his thinking, which was the ideological basis of the Revisionist Movement, is most suited in its economic thought to Western liberalism in general and to American liberalism in particular. Consequently, Jabotinsky did not believe that the Jewish State needs to be a totalitarian regime. Therefore, he believed that the idea of Jewish nationalism needs to be a representation of a collection of individuals ("kings") and not the supremacy of the State and/or the "leader".

"Revisionism is not fascist. The single idea common to it and to Italian fascism is the negation of the class war, requirement for arbitration as the sole way to resolve work conflicts, and the subjugation of the class interest to the interest of the nation. However, Revisionism believes in democracy, a parliamentary regime, freedom of thought, freedom of speech, and freedom of association." (Jabotinsky, 1933)

"I will say honestly that I do not accept on myself responsibility for the form of regime of the Hebrew State when it will be established and even our platform does not address it. I hope that this will not be a fascist regime. I believe in the freedom of speech and freedom of association, 
in the absolute equality between all people and chosen leadership. The idea of the 'leader' is considered by me to be nonsense, and I am shocked by the very thought on a 'totalitarian' state that intervenes in all the matters of civilian existence, and I prefer over it by a thousand times the worst liberalism, with all its shortcomings. In general I espouse the political outlooks of the $19^{\text {th }}$ century that are not fashionable and I adhere to the heritage of Lincoln, Gladstone, and Mazzini." (Jabotinsky, 1934b)

\section{The Influence of Liberalism on Militarism in Jabotinsky's Thoughts}

\subsection{Necessity for Military Education}

Jabotinsky saw the need for military education for the Jewish people. Following his informal education in the Jewish Brigade of the British military, he reached the understanding that military education can benefit Jewish society in an individual manner, which will cause each and every Jewish person to bring order and discipline into his life. Thus, he maintains that only the idea of war is evil in its own right. Namely, only the terrible actions that accompany war are considered unfortunate. However, he was careful to draw a separation between war and military life, unlike the Italian militarism that was expressed in the fascist idea of Mussolini's regime.

"Militarism is a contemptible word. However, adult people must not be alarmed by the sound, and it is permitted to demand of them to analyze every concept and to know to differentiate between the good and the evil in it. Evil is the war, the killing of young and innocent souls. In this we all concur, and we hope that the day will come when all this will be impossible, just like it is already impossible today in a cultural country to eat human meat, or to torture with physical tortures an accused person, as was customary before the French Revolution. However, is this the only content of military life...?"

"And the truth is that only war is ugly: military life itself excels in many good sides, when in civil life we miss them and we cannot, unfortunately, fully realize them. This is first the reciprocity in military life, the Spartan simplicity, the equality between rich and poor, and second, the hygienic factor, the pure air and the physical training, and third - the military discipline itself." (Jabotinsky, 1929)

Moreover, Jabotinsky saw it correct to bring military life to the simple Jewish citizen following the threats that exist to the Jewish people in the Diaspora and in the land of Israel. He maintains that the Jewish people persist too much in prayer and anticipation of the Messiah and not in the reinforcement of the body and fighting culture.

"For ages and generations the nations of the world were accustomed to 
hearing that here they beat the Jews and there they protected the Jews either they beat or they protected, and it is hard to say what was more humiliating - the beating or the protection. The time has come to show the world a Jewish rifle with a Jewish bayonet. From the difficulty with which we achieved this goal, you can perceive its value or perhaps it is more correct to say that we still cannot perceive all the value of this revolution - all the value and all the near and far outcomes." (Jabotinsky, 1929)

From the late 70s, there was a debate on Jabotinsky's approach to the idea of militarism. The argument revolved around two different opinions on the topic. The first opinion among the researchers saw the idea of Jabotinsky's militarism as an active idea that expresses correspondence between his opinions and the fascist ideas in Europe, an opinion that was written primarily in the researcher Avineri's book, The Zionist Idea in Its Forms (Avineri, 1980). A later opinion, which was written primarily by the researcher Naor, maintained that the essence of the idea of Jabotinsky's militarism was defensive and its implementation was intended for the self-defense of the Jewish community (Naor, 2004b). The researcher Milstein says that the militarist ideals of Jabotinsky are the basic security doctrine of the Jewish establishment in British mandate Palestine. According to his research, the head of the Jewish settlement-David Ben-Gurion, took his military doctrine from the guidelines of the militaristic doctrine of Jabotinsky (Milstein, 2016).

Regarding his approach of the theory of liberalism, today the most accepted approach in the academic literature is that Jabotinsky was a liberal and that liberalism was the fundamental influence on his thought and all his writing was based on liberal principles such as a constitutional government and human liberty (Bilsky Ben Hur, 1988).

Many articles and books were written on his approach, which shows the relationship between Jabotinsky and liberalism and it constitutes today one of the most prominent and influential approaches in the study of his doctrine. The establishment is expressed in the presentation of the writings of Jabotinsky that engage in questions of the government method, legislation, and relations of religion and state in the future Jewish State, in which he states explicitly that he supports the democratic-liberal idea and not the idea of the totalitarian "leader". Therefore, this is an empirical research approach well-established in the literature (Naor, 2004b).

\subsection{Influence of Liberalism on the Perception of Militarism in Jabotinsky's Thoughts}

It is possible to see a decisive impact of liberal ideas on the idea of militarism in Jabotinsky's viewpoint. He did not see militarism as a way of government. According to his writings, it becomes clear that he did not see militarism as a way of government or as a regime. It is certainly possible to see that he differentiated between militarism as a form of a regime and militarism as a defensive necessity. 
"Militarism means a regime in which the State has too many soldiers. This is the individual's fair use of this Latin word. However, no person, who is of clear mind, demanded that a nation will remain completely without armed forces..."

"We, the Jews, do not have this minimum of the minimum, although we are in heaven, we really need some means to 'keep the order' around the road - the Jews. I understand that when we call these militarists, who do not want to be satisfied with minimum. But to hang this collar around the necks of those who do not have anything and want to achieve at least the tenth part of the minimum, this is just blurting out words." (Jabotinsky, 1928)

\section{Conclusion}

Today it is possible to see that Jabotinsky's thinking constitutes a guiding path for political parties from all the ideological sectors in Israel and stands at the center of the political discourse between them. Therefore, when his economic-social ideas come up for discussion, in-depth research studies should be published on topics in his thinking that have not been investigated to this depth, while examining all of Jabotinsky's writings (Yachimovitz, 2011; Netanyahu, 2011).

The research literature on his philosophy has greatly discussed his political and security thinking but has less engaged and has engaged more generally in his opinions on society and the economy in society of the Jewish community in the land of Israel and in his vision for a society in the future Jewish State. Following the great amount of Jabotinsky's writings, in the field of research on his thinking it is possible to see that in-depth and in-breadth research studies are lacking on his thinking on the social and economic topics such as strikes and shutdowns, modern economics, relations between religion and state, and so on (Kramintzer \& Fox, 2012).

Over time, the Israeli historian Avineri maintained in his research study that Jabotinsky espoused fascist national ideological positions following his admiration of the national thinkers in Italy in the 1930s. According to Avineri, Jabotinsky used these nationalist theories, and he first became famous in Italy. On this basis it is necessary to read his autobiographic writings as writings that reflect his development and his national perception many years after he left Italy in his ideological struggle against socialist Zionism (Avineri, 1980).

It is certainly possible to see that the findings are commensurate with the opinions of the researchers who argue that according to Jabotinsky the liberal outlook pertains to the person's natural rights as a person, in contrast to classic and pure liberalism, which acts in the name of the free society. According to the researchers, Jabotinsky saw the state as the main factor responsible to ensure the minimal living conditions of every person (Gordon, 2013).

According to examination of his writings, it is safe to assume that, for Jabotinsky, the Liberal values were more dominated than the militaristic values. 


\section{References}

Adams, I. (1998). Ideology and Politics in Britain Today. Manchester: Manchester University Press.

Avineri, S. (1980). The Zionist Idea in Its Forms (pp. 191-195). Tel Aviv: Am Oved.

Bacevich, A. J. (2005). The New American Militarism. Oxford: University Press.

Bela, M. (1972). The World of Jabotinsky: A Selection of His Statements and the Main Tenets of His Doctrine (p. 67). Tel Aviv: Jabotinsky Institute in Israel.

Bilsky Ben Hur, R. (1988). Every Individual Is a King (pp. 26-28). Tel Aviv: Zmora Beitan Press.

Cohen, S. (1996). The IDF and Israeli Society toward Reducing the Function of the Army? In B. Kenny-Paz, \& M. Lisk (Eds.), Israel of the New Millennium (pp. 26-28). Jerusalem: Magnes.

Gordon, L. (2013). The Unknown Essays of Vladimir Jabotinsky. Jewish Political Studies Review, 9, 95-114.

Jabotinsky, Z. (1928). Memorial Day for Trumpeldor. In Memories of Members of My Generation (pp. 108-109).

Jabotinsky, Z. (1929). On Militarism. In On the Road to the State (pp. 41-42).

Jabotinsky, Z. (1933). Letter to Shlomo Yakovi (Response to the Article "Jewish Fascism", Published in Noya Veltavina, August 24 1933). In Ze'ev Jabotinsky, Letters. Tel Aviv: Jabotinsky Institute in Israel Press.

Jabotinsky, Z. (1934a). Jabotinsky's Blessing to the Foundation Committee of the National Workers' Union. In Jabotinsky's Articles. Tel Aviv: Jabotinsky Institute in Israel Press.

Jabotinsky, Z. (1934b). Letter to the Editor of the Newspaper Posledanya Novosti. In Ze'ev Jabotinsky, Letters. Tel Aviv: Jabotinsky Institute in Israel Press.

Jabotinsky, Z. (1936). The Story of My Days. In: Jabotinsky’s Articles, Tel Aviv: Jabotinsky Institute in Israel.

Kramintzer, M., \& Fox, A. (2012). On Democracy, Equality, and Individual Rights (pp. 1-7). Jerusalem: Israel Institute for Democracy.

Locke, J. (1689). Second Treatise of Government. London: Awnsham Churchill.

Milstein, U. (2016). The Crane Wheel of History. Tel Aviv: Jabotinsky Institute in Israel Press.

Naor, A. (2004a). The Constitutional Outline of Ze'ev Jabotinsky for the Jewish State in the Land of Israel. In A. Bareli, \& P. Ginosar (Eds.), Man in a Storm: Essays and Research Studies on Ze'ev Jabotinsky (pp. 58-70). Beer Sheva: Ben-Gurion University Press.

Naor, A. (2004b). With Blood and Sweat It Will Be Established for Us-The Figure of the New Jews in Jabotinsky Doctrine. In A. Bareli, \& P. Ginosar (Eds.), Man in a Storm: Essays and Research Studies on Ze'ev Jabotinsky. Beer Sheva: Ben-Gurion University Press.

Netanyahu, B. (2011). In the Knesset, in the Special Session for the Commemoration of the Death of Ze'ev Jabotinsky. http://www.youtube.com/watch?v=TR7mzeX39os

Shechtman, Y., \& Jabotinsky, Z. (1987). Story of His Life (p. 31). Tel Aviv: Karni Press.

Vagts, A. (1959). A History of Militarism. West Midlands: Meridian Books.

Yachimovitz, S. (2011). In the Knesset, in the Special Session for the Commemoration of the Death of Ze'ev Jabotinsky. http://www.youtube.com/watch?v=65G6FaAkjNo 
Submit or recommend next manuscript to SCIRP and we will provide best service for you:

Accepting pre-submission inquiries through Email, Facebook, LinkedIn, Twitter, etc. A wide selection of journals (inclusive of 9 subjects, more than 200 journals)

Providing 24-hour high-quality service

User-friendly online submission system

Fair and swift peer-review system

Efficient typesetting and proofreading procedure

Display of the result of downloads and visits, as well as the number of cited articles Maximum dissemination of your research work

Submit your manuscript at: http://papersubmission.scirp.org/

Or contact ojps@scirp.org 